\title{
“WE ARE THE WORLD”: THE FLIGHT FROM IMPOTENCE IN THE SOCIETY OF THE SPECTACLE
}

\author{
By Matt McGregor
}

Punctuating a recent music video we see, in his white glove and gold jacket, before his infamous face-whitening surgeries, the Michael Jackson of old. This video, for the song "We are the World 25,” is introduced, directly into camera, by a sincere Jamie Foxx, who implores viewers to give generously to help the recovery effort in Haiti. "Do more than just watch," he says. “Take action.” Then, before the expected images of Haitians, and even before the singing celebrities themselves, we see a host of signatures unfolding on a black background. From the beginning, then, this video walks a very thin line: clearly banking on the reputations of singers who have made their careers as spectacles, as images, the video goes to some lengths to claim an authentic, and even superior, political position. "Give what you can," Jamie Foxx says, “as I have.”

The video's repeated use of the image of Michael Jackson signifies this tenuous, if not contradictory, position. Who, after all, is more exemplary of the cultural logic of the society of the spectacle than Michael Jackson? And who, in the pantheon of MTV singers, spent more time claiming authenticity and declaring our collective responsibility for a universal humanity? The video presents an excess of repetition and citation, in terms of its music and lyrics, the images Michael Jackson himself, as well as the chorus of Jackson-citing celebrity singers. But, despite the obvious point that these images and these performers are perhaps the most manufactured and least authentic imaginable, the video's authenticity, as well as its anxiety over its own search for authenticity, is almost hyperbolically announced. My goal in this short essay is to read this video in relation to Agamben's claims about the spectacle in his 
book The Coming Community. I will argue that it is precisely this citationality, this identity without essence-what is clearly a profoundly inauthentic announcement of authenticity— that Agamben sees as, potentially, the road out of the spectacle society. This video promises what Agamben calls “whatever” politics (1), so-called politics, or, in Derrida’s terminology, a politics "under erasure” (OG 23). At the same time, this video reveals the parallel logic, suggested in juridical terms in Agamben's Homo Sacer, in which the anxiety of nonbelonging and inauthenticity leads to a more extreme and potentially violent search for essential group belonging and authentic political identity.

In the middle of Agamben's The Coming Community, we find a section entitled "Dim Stockings," which begins with a discussion of a French advertisement from the 1970s. Featuring stockinged French women riding mules and celebrating in the sun, the ad ends with five women dancing, each with her own individual rhythm, to no coherent choreography, to the same tune. They appear to be dancing together, in a group; yet, at the same time, they are completely individual. The strange allure of the commercial is explained, according to Agamben, by the fact that each of the dancing women was shot individually and only later brought into a single image and under a single soundtrack. Agamben claims that this "facile trick, that calculated asymmetry of the movement of long legs sheathed in the same inexpensive commodity, that slight disjunction between the gestures, wafted over the audience a promise of happiness unequivocally related to the human body” (46).

Jean Baudrillard, in an early essay entitled “The System of Objects,” refers to this production of happiness as the "new humanism" of consumer culture (13). In this essay, he refers to Dr. Dichter, one of the founders of focus group marketing, who argues that commodity culture represents a new stage in human happiness, in which human beings will no longer feel guilty about enjoying their lives. Commodity culture, Dichter argues, promises 
a new era of fulfillment, in which we will all be able to express our true and unique selves in what Baudrillard calls "the system of objects.” Commodity culture promises to set us free; it promises to release our repressed desires so that we may be our authentic selves.

Baudrillard's critique of Dichter is, in retrospect, an obvious one: the apparent freedom promised by commodities is simply the freedom to participate in commodity culture. Rather than releasing our repressed drives, commodity culture in fact censors them more effectively by offering the mere appearance of release in the consumption of the commodity. Advertising, for Baudrillard, promises an idea of what we might call a fulfilled, happy, and vital life, only to channel and frustrate that idea in the commodity (24).

For Agamben, the promise of happiness we see in "Dim Stockings” is not so easily set aside. In the 1920s, he argues, when the commodification of the human body became widespread, even "observers who were by no means favorable to the phenomenon could not help but notice a positive aspect to it, as if they were confronted with the corrupt text of a prophecy that went beyond the limits of the capitalist mode of production and were faced with the task of deciphering it” (46). The exemplary case of this is Walter Benjamin's thesis on the "decay of the aura.” For Agamben, this aura refers not only to the aura of the artwork but to the aura of the human body itself. The commodification of the body, to quote Samuel Beckett’s Watt, works to “eff the ineffable," that is, express the inexpressible (61). It becomes, for Agamben, “perfectly communicable, entirely illuminated” (47). These women—reduced to spectacles and represented, like the stockings they sell, as iterable commodities—surely reveal, as Agamben admits, "the complete domination of the commodity form over all aspects of social life” (48). The bodies of these women, these images, lack all aura and mystery: they are pure exchange value. Never, Agamben writes, "has the human body--above all the female body--been so massively manipulated as today 
and, so to speak, imagined from top to bottom by the techniques of advertising and commodity production” (48). The problem for Agamben, however, is not simply the commodification and manipulation of the body. Rather, the problem is that advertising promises a new way of thinking of the body on which it does not materially deliver. What he calls the "glorious body of advertising" is a front, a mask, behind which lies the figure of homo sacer. The dancing women in their "geometrical splendor [...] covers over the long lines of the naked, anonymous bodies led to their death in the Lagers (camps), or the thousands of corpses mangled in the daily slaughter on the highways” (49).

The problem, then, is not that the aura, the mystery, and the ineffability of the living body is lost, but that it is only represented as lost and that this representation produces an anxiety about the mystery and ineffability of the body which can never be fulfilled by the commodity itself. This representation of the loss of the mystery of the body, and of the authentic life, leads to an even more extreme desire for mystery and authenticity. The society of the spectacle, by representing life as lifestyle and identity as choice, produces a more intense search for authenticity, a more fervent search for essences, and a more desperate desire for the life which transcends lifestyle. This search is, as Agamben puts it, a flight from impotence. The necessary failure of this flight or search in the society of the spectacle leads to what Agamben calls the zone of indistinction, in which one is anxious and never sure of one’s authenticity, be it in terms of gender, sexuality, nationality, or cultural identity. As anthropologist Arjun Appadurai has pointed out, this anxiety in the face of indistinction, where the global flows of iterable images everywhere mark the negation of essence, has led, globally, to a rise in essentialist nationalisms and fundamentalisms. Accompanying this, we see a rise in "ethnic cleansing," born from what Appadurai calls the “fear of small numbers.” Appadarai’s gruesome point is that genocide is, after all, an 
expression of group cohesion, an “exercise in group cohesion,” as Phillip Gourevitch puts it (qtd. in Appadurai 7). This logic is, as some readers might have noticed, analogous to what Agamben calls the logic of the camp, whereby the confusion between what is inside and outside the polis, what is zoe and what is bios, produces an anxiety which leads to the creation of a topos in which the law withdraws to a state of pure potentiality. The desire for a pure inside, an inside that is under the protection of the law and purified from any outside, from any pollution of non-belonging, leads paradoxically to the law's withdrawal in the form of a state of emergency. This leads to a zone of indistinction in which neither inside nor outside, citizen nor terrorist can be distinguished, and in which everyone lives under the possibility that they, too, will be weeded out of the walled garden, and that they, too, will become homo sacer. As Agamben points out, “The meaning of ethics becomes clear only when one understands that the good is not, and cannot be, a good thing or possibility beside or above every bad thing or possibility, that the authentic and the true are not real predicates of an object perfectly analogous (even if opposed) to the false and the inauthentic” (12). Thus, we see in The Coming Community and Homo Sacer Agamben's suspicion of walls and laws, both of the state and of the self.

As these references to Homo Sacer and the state imply, Agamben's discussion of authenticity in The Coming Community centers on the concept of belonging. Throughout the book, we follow the refrain of "being red, being Communist, being Italian.” Against belonging, and against authenticity, Agamben proposes a series of formulations that could mark the community to come. In discussing Robert Walser's fiction, he suggests that "The semantic status of his prose coincides with that of the pseudonym or the nickname” (58). In Walser's prose, it is as though every word is merely "so-called.” Thus, we have so-called red, so-called communist, so-called Italian. This is not a case of belonging-but nor is it non- 
relational, non-belonging. Being "so-called Italian” is to be neither inside nor outside the set "Italian.” It is, as he suggests elsewhere in the book, to be an exemplary Italian, with the example being that which is both a particular instance (it is Giorgio Agamben who is Italian) and an instance of the whole (Agamben is typical of all Italians) (9). This is a form of nonessentialist belonging, inauthentic belonging, or, in Agamben’s words, “whatever” belonging. This belonging is purposive without purpose; it is a belonging which lacks a concept. Interestingly, it is the spectacle- that which marks the destruction of aesthetics, which reduces every aesthetic judgement to, as Alan Liu puts it, “cool or not cool”-that Agamben suggests may fulfill the promise of the Kantian aesthetic (3).

This “whatever” belonging represents, for Agamben, the potential or promise of the spectacle society. The exemplar of the whatever is the planetary petit-bourgeoisie, a class which refuses to be a class, a class which refuses "any recognizable social identity" (62). As Agamben puts it, “The petty bourgeois nullify all that exists with the same gesture in which they seem obstinately to adhere to it: They know only the improper and the inauthentic and even refuse the idea of a discourse that could be proper to them.” The diversities of cultural identity that "have marked the tragicomedy of universal history are brought together and exposed in a phantasmagorical vacuousness.” The problem, again, with this vacuousness, this reign of the signifier, is that the petit-bourgeoisie still maintain, in the realm of nonbelonging, their belief in the signified purity of belonging. "Nothing,” Agamben writes, referring tacitly to the opening of Baudrillard's essay "System of Objects,"

Resembles the life of this new humanity more than advertising footage from which every trace of the advertised product has been wiped out. The contradiction of the petty bourgeois, however, is that they still search in the footage for the product they were cheated of, obstinately trying, against all 
odds, to make their own an identity that has become in reality absolutely improper and insignificant to them. (62)

It is the end of this "search" that we can look forward to in the coming community. What we have in the society of the spectacle and the planetary bourgeoisie is, as Agamben admits, a form of humanity moving "towards its own destruction” (65). But in this probability of destruction is an opportunity,

Because if instead of continuing to search for a proper identity in the already improper and senseless form of individuality, humans were to succeed in belonging to this impropriety as such, in making of the proper being-thus not an identity and an individual property but a singularity without identity, a common and absolutely exposed singularity-if humans could, that is, not bethus in this or that particular biography, but be only the thus, their singular exteriority and their face, then they would for the first time enter into a community without presuppositions and without subjects, into a communication without the incommunicable. (65)

We have, here, the promise of an "exposed singularity," a singular exteriority. For Agamben, this is promised by the realization, forced upon us in the society of the spectacle, that our qualities, our apparent markers of identity, like gender and nationality, are not expressions of biology or essence, but are, as Judith Butler has taught us, citational and iterative. They come, that is, from without. The endless circulation of the image in the spectacle society threatens to destroy all auras. It shows the social and historical constitution of all essences. It exposes the inherent exteriority of the inside, or the inauthentic which haunts all assertions of authenticity.

So, what we take to be our essence is constituted by exteriority; it is thus inauthentic, 
unreal, unauthorized. The women of dim stockings, who are both individual, in the dissonance of the dance, and yet who are also clearly iterations, cut from the same commodity cloth, intimate the nature of this community of the inauthentic. The spectacle, as defined by Debord, is that which separates life from itself: it is when the stuff of life, the relations between humans, are always already mediated by images. For Agamben, this mediation, the citationality of the image, can work to disrupt old myths of essence and belonging, to a form of so-called belonging that is always already vicarious, external, iterative, and substitutable.

If we had more time, I would turn here to Homo Sacer in more detail—for it is clear that, for Agamben, and for us all, this promise of the spectacle remains profoundly unfulfilled. Against several prominent misreadings of Agamben, the zone of indistinction, the zone of homo sacer, the society of the spectacle, and the state of emergency do not represent the coming community; rather, the coming community is an opportunity produced by these violent and senseless states and zones. And yet, when he refers to opportunity, and when I refer to an unfulfilled promise, it is tempting to think of goals and tasks, of plans and strategies. For Agamben, though, to speak of historical tasks is to leave the sphere of ethics. The fact, he argues, "that must constitute the point of departure for any discourse on ethics is that there is no essence, no historical or spiritual vocation, no biological destiny that humans must enact or realize” (42). A politics of destiny, or essence, or vocation, will, Agamben implies, merely reproduce the problematic social and juridical structures we live under, in the contemporary states of emergency.

We return, now, to the obvious politics of destiny and essence in "We are the World 25.” It is, I'd suggest, the clear and present fact of inauthenticity produced by the spectacle that leads to the song's solemn requests, unfolding autographs, and hyper-emotive vocals. 
The song's essentialist hyperbole is a response to the anxiety of authentic political participation in the society of the spectacle. The logic of the music video is the logic of the commodity form itself, of iteration and the negation of essence. In terms of politics and identity, the music video thus produces anxiety; it threatens, with its iterative logic, to dismantle the continuities of cultural belonging once guaranteed by both the polis and the family. Indeed, such hyperbolic claims to an authentic politics is an intimation of the spectacle’s own absurdity before Haiti and, perhaps, its own culpability as a mask before these bare lives in a society recently turned, if only briefly, into a camp by swooping security forces from America and elsewhere. Agamben suggests such culpability several times in Homo Sacer and The Coming Community. In the reified society of the spectacle, Agamben argues that we have a choice: we will continue to search, ever more desperately, for a perfectly walled we, a pure and authentic collectivity, and see a continual rise in the incidence of the camp; or else we will see the coming community, the so-called we of the whatever world. 


\section{Works Cited}

Agamben, Gorgio. The Coming Community. Trans. Michael Hardt. Minneapolis: U of Minnesota P, 2007. Print.

Appadurai, Arjun. Fear of Small Numbers. Print.

Artists for Haiti feat. Michael Jackson. “We are the World 25 for Haiti.” Prod. Quincy Jones, Lionel Ritchie and Wyclef Jean. 2010. Web.

Baudrillard, Jean. “The System of Objects.” Selected Writings. Ed. Mark Poster. Trans. Jacques Mourrain. Palo Alto: Stanford UP, 2002. Print.

Beckett, Samuel. Watt. New York: Grove Press, 1994. Print.

Butler, Judith. Undoing Gender. New York: Routledge, 2004. Print.

Debord, Guy. The Society of the Spectacle. Trans. Ken Knabb. Canberra: Hobgoblin P, 2002. Print.

Derrida, Jacques. Of Grammatology. Trans. Gayatri Chakrovorty Spivak. Baltimore: John Hopkins UP, 1997. Print

Liu, Alan. The Laws of Cool: Knowledge Work and the Culture of Information. Chicago and London: U of Chicago P, 2004. Print. 